\title{
Kualitas Apartemen pada Keberlangsungan Kehidupan Penghuninya dalam Konteks Perilaku Lingkungan
}

\author{
Susy Budi Astuti ${ }^{1}$, Prasetyo Wahyudie ${ }^{2}$ \\ ${ }^{1,2}$ Departemen Interior, Fakultas Arsitektur, Desain, dan Perencanaan, ITS Surabaya \\ Jl. Raya Keputih, Sukolilo - Surabaya 60119 Telp 031.5925223 \\ ${ }^{1}$ susy@interior.its.ac.id, 2prasetyo@interior.its.ac.id
}

\begin{abstract}
ABSTRAK
Studi perilaku lingkungan terdiri atas komponen setting, user group dan behavioral phenomena. Karakter setting (tempat/lingkungan) berpengaruh pada perilaku penggunanya. Berdasarkan hal tersebut, maka lingkungan fisik mendasari perilaku penghuni apartemen. Perbedaan karakter lingkungan menimbulkan perbedaan karakter perilaku penghuninya. Penelitian ini bertujuan menemukan keterkaitan karakter lingkungan apartemen yang berdampak pada perilaku penghuni apartemen, guna memperoleh keberlangsungan kehidupan di hunian vertikal khususnya apartemen.

Penelitian bersifat naturalistik, dengan pendekatan fenomenologi. Observasi dilakukan dengan cara mengamati perilaku dan jejak fisik. Untuk menggali lebih mendalam tentang penghuni dan lingkungannya serta alasan penyebabnya dilakukan wawancara terstruktur.

Karakter lingkungan apartemen secara fisik berpengaruh pada karakter perilaku penghuninya dalam memanfaatkan fasilitas penunjang di apartemen. Sedangkan perilaku penghuni dalam beraktivitas di fasilitas penunjang apartemen berdampak besar pada karakter perilaku yang terjadi di ruang bersamanya. Adanya dampak tersebut, maka karakter perilaku yang terbentuk menjadi keberlangsungan kehidupan penghuni apartemen.
\end{abstract}

Kata kunci: kualitas apartemen; perilaku penghuni

\section{ABSTRACT}

Environmental Behavior Studies consist of components of settings, user groups and behavioral phenomena. Character settings (place / environment) affect the behavior of users. Physical environment determine the behavior of apartment residents. Differences in the character of the environment give rise to different characteristics of the occupants. This study aims to find the relationship of the character of the apartment environment that has an impact on the behavior of apartment occupants, in order to obtain continuity of life in vertical housing, especially apartments.

Research is naturalistic, with a phenomenological approach. This research used observation method by observing behavior, physical traces and. structured interviews. The character of the apartment environment physically influences the character of the occupants' behavior in the supporting facilities in the apartment. Character occupant's behavior in apartment support facilities has a major impact on the character of behavior that occurs in the shared space. The existence of these impacts, the character of the behavior becomes the sustainability living of the apartment occupants.

Keyword: apartment quality; occupant behavior

\section{PENDAHULUAN}

Menurut Snyder (1979), studi tentang hubungan lingkungan dan perilaku manusia serta aplikasinya pada proses desain disebut studi perilaku lingkungan atau lebih dikenal dengan istilah Environment Behaviour Studies (disingkat EBS). Studi EBS dalam bidang ilmu arsitektur tidak hanya tentang studi keberadaan fungsi suatu obyek atau ruang, namun lebih mempelajari bagaimana kualitas ruang sehingga manusia dapat dengan mudah memanfaatkan fungsi satu ruang dengan yang lain. Altman (1980) menjelaskan bahwa studi perilaku lingkungan/EBS menyangkut 3 komponen, yaitu environment-behaviour phenomena, user group dan settings. Fenomena perilaku terhadap lingkungan akan berbeda-beda, karena terjadi 
Susy Budi Astuti, Prasetyo Wahyudie

Kualitas Apartemen pada Keberlangsungan Kehidupan Penghuninya dalam Konteks Perilaku Lingkungan

perbedaan meaning, simbol serta cara manusia memanfaatkan lingkungan sebagai representasi diri. Privasi adalah sebuah perilaku personal yang terkait dengan pola perilaku individu, peraturan dan sistem sosial lingkungannya. Perbedaan user groups akan memunculkan perbedaan needs dan pola aktivitas, sedangkan settings menurut Altman adalah skala lingkungan tempat perilaku berlangsung.

Berdasarkan lingkup EBS, maka studi perilaku lingkungan merupakan interaksi timbal balik dari komponennya. Menetapkan user group yang diteliti dengan pengamatan fenomena perilaku tertentu pada fisik yang tertentu pula. Pada konsep arsitektural hal tersebut dikenal sebagai kajian behavior setting. Haryadi dan Setiawan (1995) lebih lanjut menjabarkan behavior setting atas 2 bentuk yaitu system of setting dan system of activity. System of Setting adalah sistem rangkaian elemen elemen fisikal dan spasial dalam hubungan tertentu yang saling terkait digunakan untuk kegiatan tertentu. Sedangkan system of Activity adalah sistem kegiatan sebagai rangkaian perilaku yang sengaja dilakukan oleh satu atau beberapa orang.

Sebelumnya, Barker (1955) mendifinisikan EBS dalam 4 karakter, yaitu a standing pattern of behavior (perilaku individu), social rules (norma), physical environment (ruang sosial, ruang privasi dll) dan time locus (batasan waktu, misalnya jam, hari atau bulan). Sehingga nampak jelas bahwa studi perilaku lingkungan merupakan studi perilaku manusia sebagai individu maupun sosial (group komunitas) terhadap lingkungan fisik, selain mengkaji fungsi fisik (needs) juga non fisik.

Penelitian Farida (2013) menunjukkan bahwa kualitas fisik ruang luar menentukan perilaku penghuninya dalam beraktivitas dan berinteraksi dengan lingkungannya. Keberadaan dan konfigurasi ruang luar mempengaruhi pola perilaku anak. Adanya perbedaan konfigurasi letak ruang ruang bersama mengakibatkan perbedaan fungsi 'manfaat' ruang luar tersebut. Aziz dkk (2013) menjelaskan bahwa ruang luar terbuka yang dekat dengan hunian sangat penting untuk arena bermain anak. Interaksi sosial yang baik dengan tetangga berdampak pada pertumbuhan psikologis kehidupan anak. Namun hal tersebut menjadi problem pada high rise housing, utamanya pada low income. Penelitian ini menunjukkan bahwa ada perbedaan manfaat dan penggunaan ruang luar bersama dikaitkan dengan lokasi. Ruang luar bersama di lantai dasar lebih disenangi daripada di lantai teratas. Aziz dkk menekankan bahwa perbedaan secara fisik (lokasi) sangat mempengaruhi adaptasi perilaku anak anak. Anak anak memerlukan social environment di dekat rumah. Penelitian Aziz dkk tersebut lebih mencermati ruang bersama pada high rise - low income housing. Perbedaan taraf ekonomi akan berbeda pula gaya hidupnya. Penelitian ini akan difokuskan pada penghuni golongan menengah ke atas yang menempati hunian vertikal modern (apartemen), dengan pendekatan perilaku personalisasi ruang bersama.

Menurut Rapoport (1986), lingkungan fisik dapat menentukan perilaku manusia (environmental determinism), lingkungan fisik menyediakan batas yang di dalamnya manusia dapat memilih (environmental possibilism) atau lingkungan fisik menyediakan pilihan/mengarahkan namun tidak menentukan (environmental probabilism).

Manusia cenderung memberi tanda atau simbol untuk mengidentifikasi ruang yang dimiliki, Altman (1976) menyebut hal ini sebagai perilaku personalisasi ruang. Oleh karenanya personalisasi ruang tidak hanya membahas privasi individu/kelompok tertentu, namun juga bagaimana aspek tersebut hadir di lingkungan publik. Karakter perilaku sangat berkaitan dengan karakter lingkungannya. Jenis bangunan yang sama, namun pada lingkungan yang berbeda maka menyebabkan perilaku penghuni bangunan yang berbeda pula. Interaksi keduanya menjadi dasar dalam merumuskan karakter perilaku. Dijelaskan oleh Snyder (1979) bahwa fenomena perilaku sangat berkaitan dengan setting/place dan user group nya. Diperjelas lagi oleh Lang (2010) bahwa place sebagai setting tempat tidak dapat berfungsi sebagaimana yang diinginkan pemakainya bila tidak ada link yang saling mempengaruhi. 


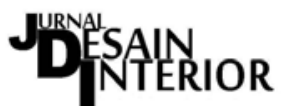

Vol. 3, No. 2, Desember 2018, pISSN 2527-2853, eISSN 2549-2985

Berdasarkan kajian penelitian penelitian tersebut, maka penelitian ini bertujuan ingin mengetahui dan merumuskan karakter lingkungan, karakter perilaku penghuni serta hubungan antara karakter lingkungan dengan karakter perilaku penghuni, sebagai pembentuk keberlangsungan kehidupan penghuni pada hunian vertical, khususnya apartemen.

Beranjak dari fenomena beragamnya klasifikasi apartemen dan karakter lingkungan yang berbeda beda, maka perlu ditentukan kriteria apartemen sebagai obyek penelitian. Yaitu sebagai berikut 1) tidak terintegrasi dengan fasilitas umum lain (hotel/mall/lainnya), 2) di dalam kawasan perumahan serta berada di lingkungan perguruan tinggi, 3) mempunyai ruang bersama berupa lobi dan koridor, 4) tipe unit yang tersedia studio/1-3 bedroom, maka apartemen di Surabaya yang merepresentasikan kriteria tersebut dipilih apartemen Purimas. Selain berada di kawasan permukiman apartemen tersebut juga berada di lingkungan pendidikan, utamanya dekat dengan kampus yang cukup ternama di Surabaya, yaitu UPN Surabaya.

Karakter kawasan permukiman dan pendidikan tersebut memunculkan fasilitas umum penunjang hunian dan pendidikan. Misalnya, sekolah, pasar, toko kebutuhan pokok rumah tangga, minimarket, toko alat tulis dan fotocopy, warung/rumah makan, jasa laundry serta angkutan umum (Gambar 1). Keberadaan dan jenis fasilitas umum tersebut berdampak pada pola perilaku penghuni apartemen. Terjadi interaksi sosial penghuni apartemen dengan lingkungannya.

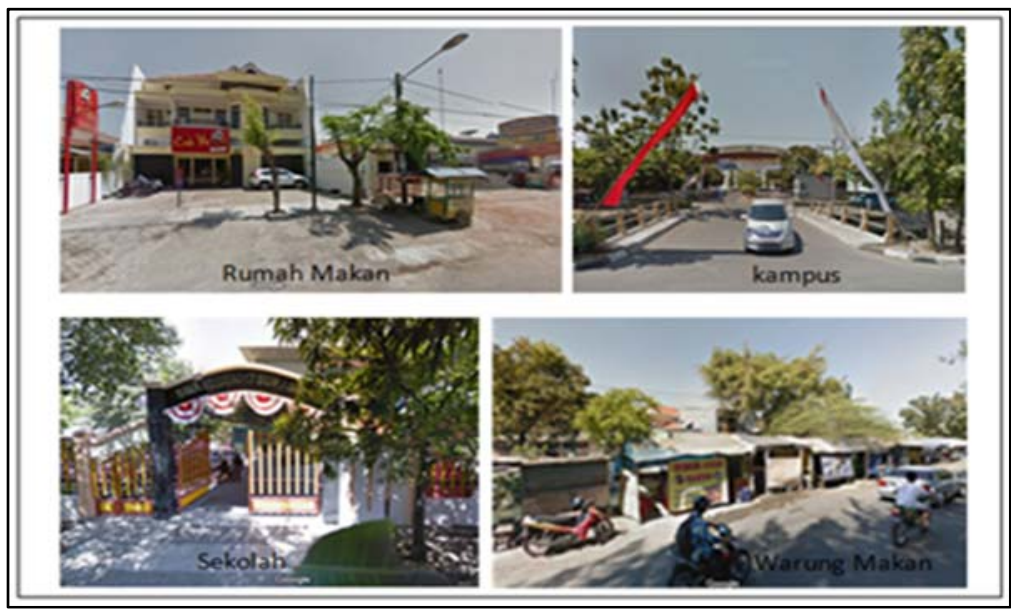

Gambar 1. Karakter Lingkungan Fisik Apartemen di Wilayah Permukiman dan Pendidikan Sumber: Observasi Peneliti (2006)

\section{METODE PENELITIAN}

Penelitian ini menggunakan metode kualitatif melalui pendekatan fenomenologi. Metode kerja menggunakan analisa Zeisel (1984), yaitu melalui pengamatan perilaku (observing behavior), pengamatan jejak fisik (observing physical traces) dan wawancara terstruktur (kuisioner). Pengamatan jejak fisik dilakukan pada kondisi fisik lingkungan meliputi jenis sarana, letak, sirkulasi dan karakter ruang. Pengamatan perilaku dilakukan pada penghuni apartemen serta interaksinya dengan pengunjung/petugas. Wawancara dilakukan terhadap penghuni secara random namun purposive guna mengetahui beberapa alasan yang tidak dapat diperoleh melalui pengamatan perilaku maupun pengamatan fisiknya. Ketiga metode kerja tersebut diterapkan dalam penelitian ini, karena selain mudah dilakukan, kredibilitas dapat dicapai dengan pengulangan pengamatan serta dapat mengungkap kejadian kejadian yang kemungkinan di luar prediksi atau jarang terjadi. 


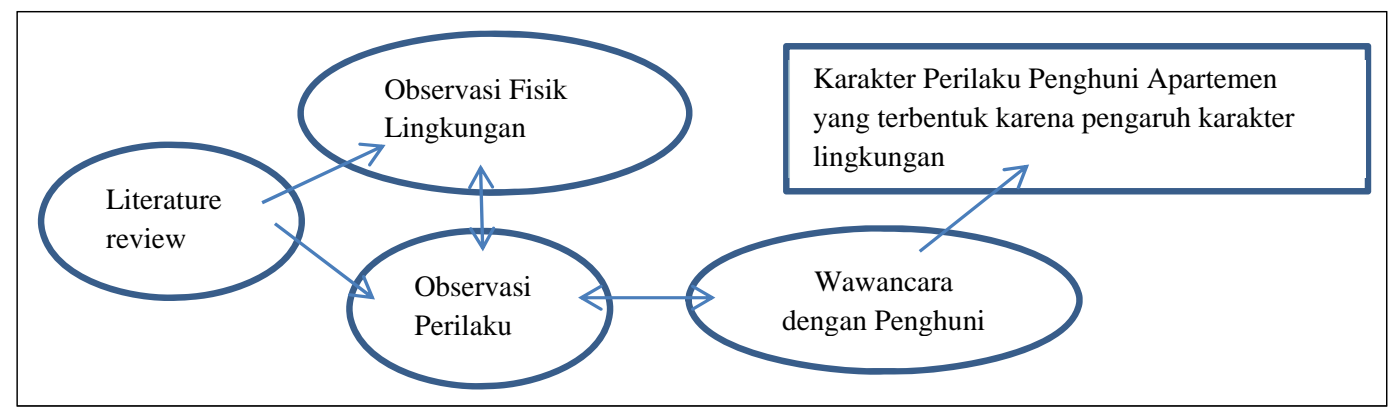

Gambar 2. Alur Pikir Penelitian

Sumber: Astuti, SB (2018)

\section{HASIL PENELITIAN DAN PEMBAHASAN}

Apartemen Purimas terletak di perumahan Purimas, Kecamatan Rungkut kota Surabaya. Karakter lingkungan didominasi oleh usaha makanan, mini market, pertokoan dan sekolah. Promenade Purimas, pedagang kaki lima, rumah makan franchise banyak terdapat di sekitar apartemen. Demikian pula beberapa franchise minimarket. Pertokoan pun menjual barang yang berkaitan dengan kebutuhan rumah tangga, yaitu alat tulis, bahan bangunan, apotik, mebel, handphone, jasa laundry dan cuci mobil. Fasilitas-fasilitas tersebut dapat dicapai dengan berjalan kaki 5 - 10 menit. Sebagai contoh, pedagang sayur nampak rutin setiap pagi mangkal di ruko depan apartemen. Sambil jalan pagi, nampak beberapa penghuni apartemen belanja di depan ruko tersebut. Demikian pula jasa laundry, mereka men ‘jemput bola’ ke apartemen. Setelah sepakat melalui hubungan telpon, penghuni apartemen dan petugas laundry bertemu di selasar depan lobi atau jalan trotoar depan apartemen.

Apartemen Purimas mempunyai karakter batas lahan bagian depan berupa tanaman dan trotoar. Secara visual dan fisik, lingkungan apartemen menyatu dengan lingkungan luar. Penghuni dapat berinteraksi secara visual, misal menunggu jemputan-taxi, menunggu penjual sayur, pedagang makanan keliling maupun petugas laundry. Hal tersebut dapat dilakukan dari dalam lobi maupun dari halaman parkir depan. Secara fisik penghuni juga dapat mencapai dan mengakses luar apartemen dengan mudah. (Gambar 4 dan 5)

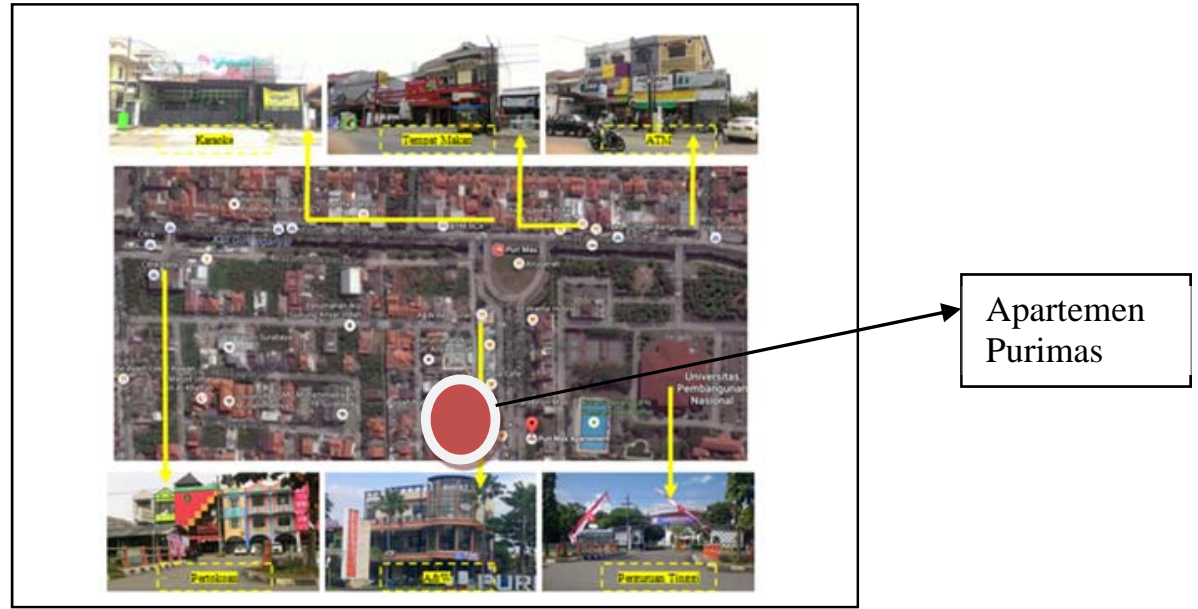

Gambar 4. Karakter Lingkungan di Sekitar Apartemen Purimas Sumber: Hasil Observasi (2016) 


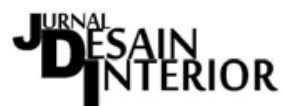

Vol. 3, No. 2, Desember 2018, pISSN 2527-2853, eISSN 2549-2985

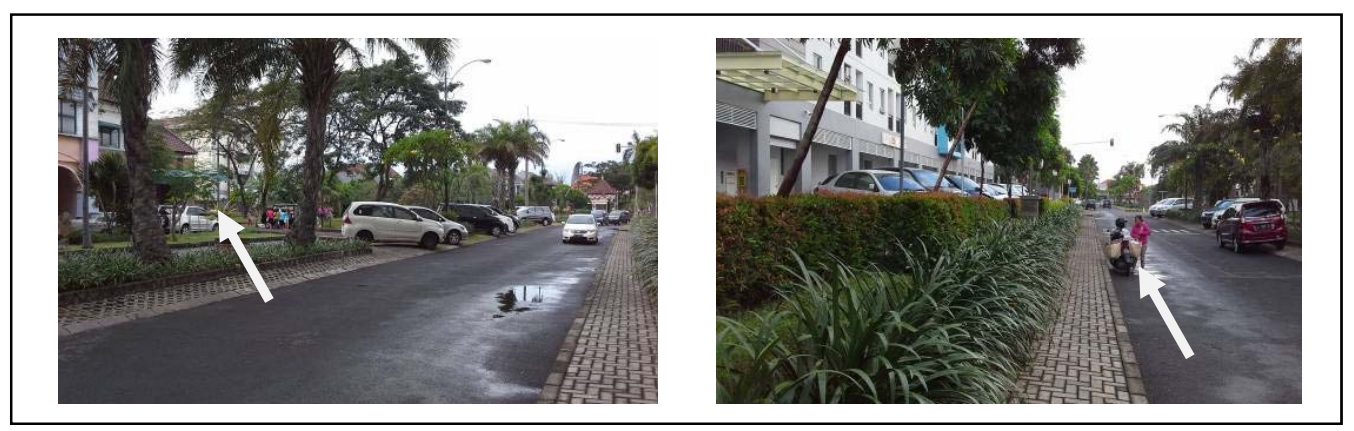

Gambar 5. Batas Fisik Tanaman Serta Trotoar di Halaman Depan Apartemen Purimas Sumber: Hasil Observasi (2016)

Fisik apartemen Purimas berbentuk 1 tower yang terdiri atas 14 lantai (Gambar 6), 624 satuan unit apartemen, 9 toko dan 27 kios. Apartemen Purimas tidak terintegrasi dengan fasilitas publik lain seperti mall atau perkantoran. Lantai 1 berfungsi sebagai fasilitas penunjang, yaitu kolam renang, foodcourt, mini market/toko serta sarana parkir. Adapun lantai 2 hingga 14 adalah tipikal hunian berupa unit kamar.

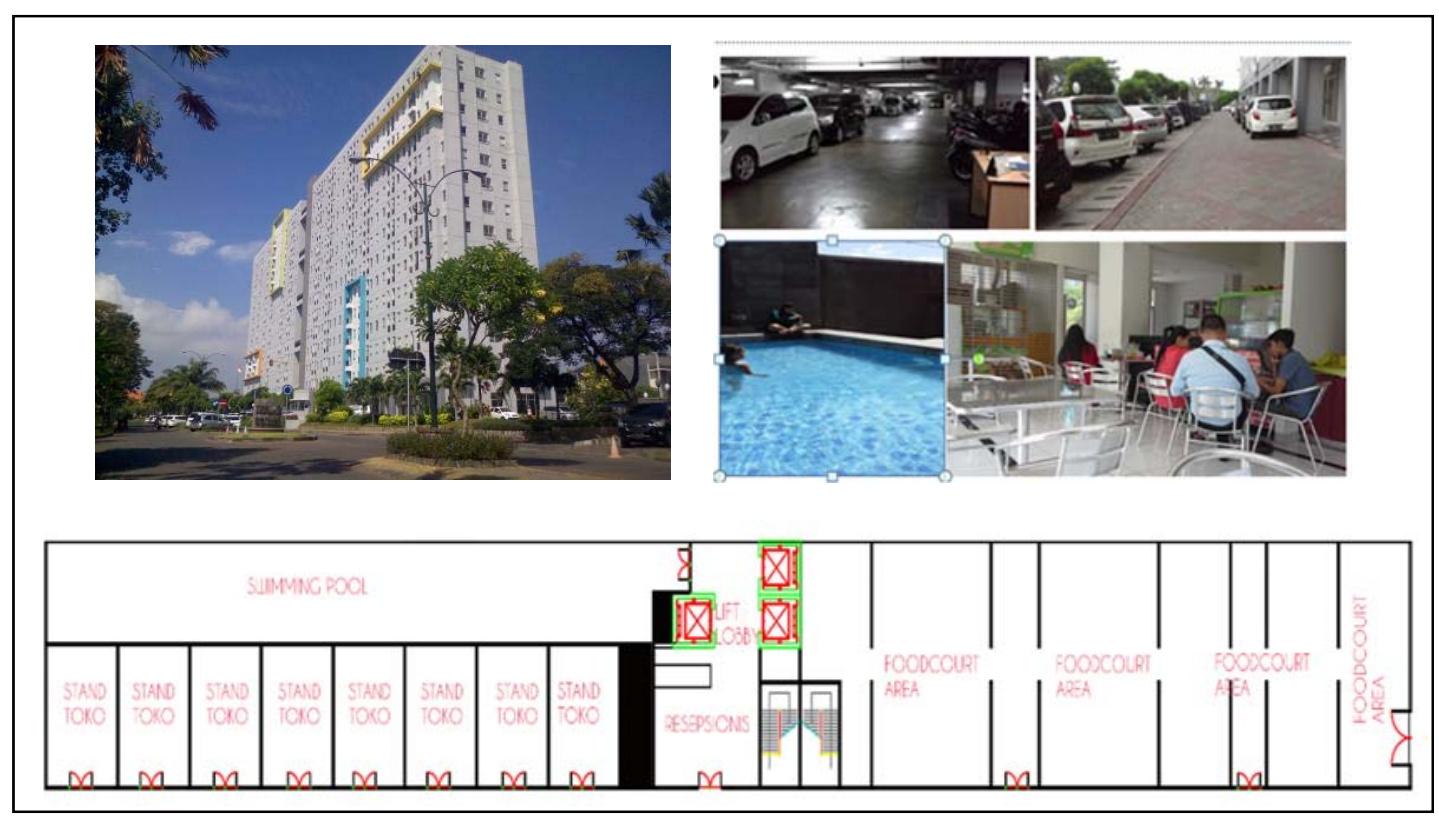

Gambar 6. Tampak Depan, Denah Lantai 1 dan Fasilitas Penunjang di Lantai 1 Apartemen Purimas Sumber: Hasil Observasi (2016)

Berdasarkan layout ruang di lantai 1, maka sirkulasi penghuni berpusat di ruang lobi. Karena lobi apartemen Purimas merupakan satu satunya ruang tempat mengakses unit kamar di lantai atas. Selain mengakses unit kamar di lantai atas, kolam renang merupakan fasilitas penunjang yang juga hanya dapat diakses dari lobi. Artinya, sirkulasi pengguna yang masuk ke lobi adalah yang berkepentingan dengan unit kamar dan kolam renang (Gambar 7). Fungsi kontrol selain oleh petugas di lobi juga oleh petugas di pos jaga yang terletak di pintu masuk halaman apartemen. 


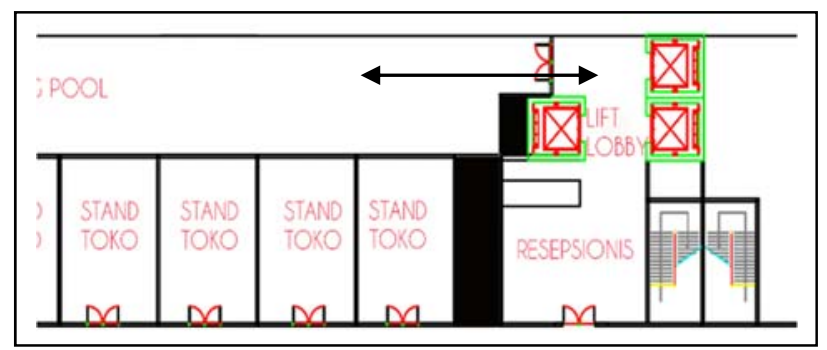

Gambar 7. Sirkulasi Pengguna di Lantai 1, ke Unit Kamar dan Kolam Renang Sumber: Hasil Observasi (2016)

Sedangkan fasilitas penunjang lain yang terletak di lantai satu yaitu toko dan foodcourt menghadap ke halaman depan apartemen. Sehingga fasilitas tersebut dapat diakses oleh pengunjung . Bersifat publik karena pengunjung dapat mengakses fasilitas tersebut tanpa harus melewati lobi (Gambar 8). Fungsi kontrol dilakukan oleh petugas di pos jaga ketika masuk halaman apartemen. Pada Apartemen Purimas, ruang lobi terdiri dari area resepsionis, tempat duduk sofa. Dari ruang lobi penghuni dapat langsung mengakses area lift atau kolam renang yang berada di belakang resepsionis. Suasana lobi pada apartemen ini terbilang cukup ramai karena ruangan tersebut menjadi pusat aktivitas bersama yang utama, dimana penghuni yang turun dari lift bertemu dengan penghuni yang memasuki lobi (Gambar 7).

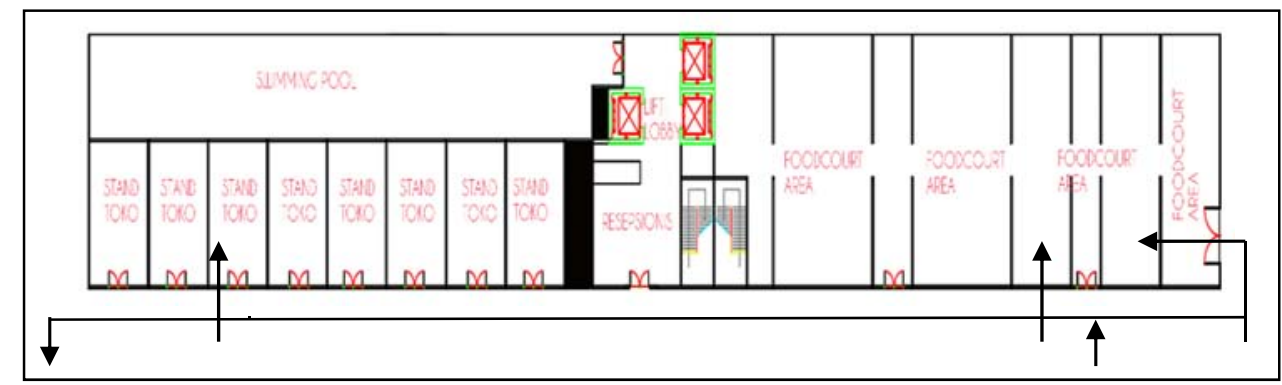

Gambar 8. Sirkulasi Pengguna di Lantai 1, ke Toko dan Foodcourt Sumber: Hasil Observasi (2016)

Lantai 2 hingga 14 berfungsi sebagai hunian (unit kamar), dimana dari denah tersebut dapat diketahui hunian lebih di dominasi oleh tipe unit studio dibandingkan dengan tipe unit dua bedroom. Hal ini dapat dikarenakan lokasi apartemen yang berdekatan dengan lokasi pendidikan jenjang perguruan tinggi yang memiliki pangsa pasar mahasiswa yang lebih membutuhkan tempat tinggal tipe studio. Desain layout ruang yang simetris membentuk pola sirkulasi yang terpusat di area tengah yaitu area lift (Gambar 9).

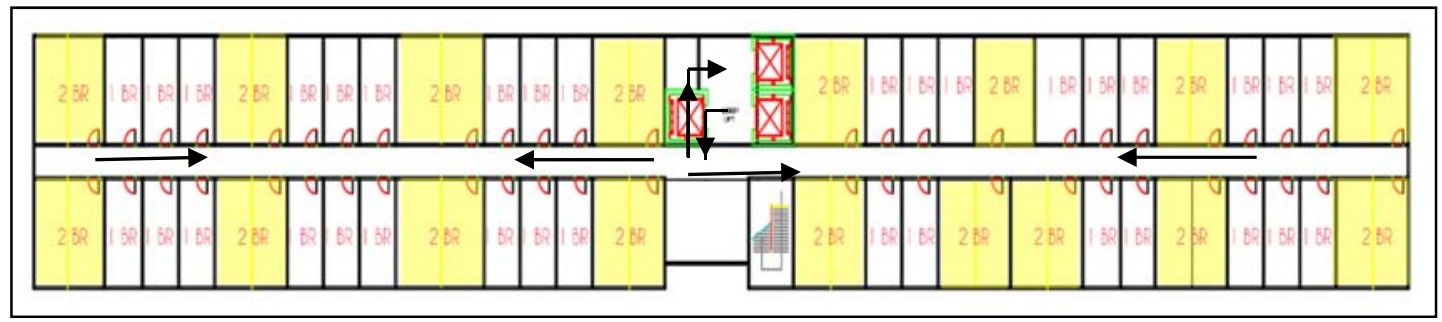

Gambar 9. Denah Tipikal Lantai 2 - 14 Apartemen Purimas Sumber: Hasil Observasi (2016) 


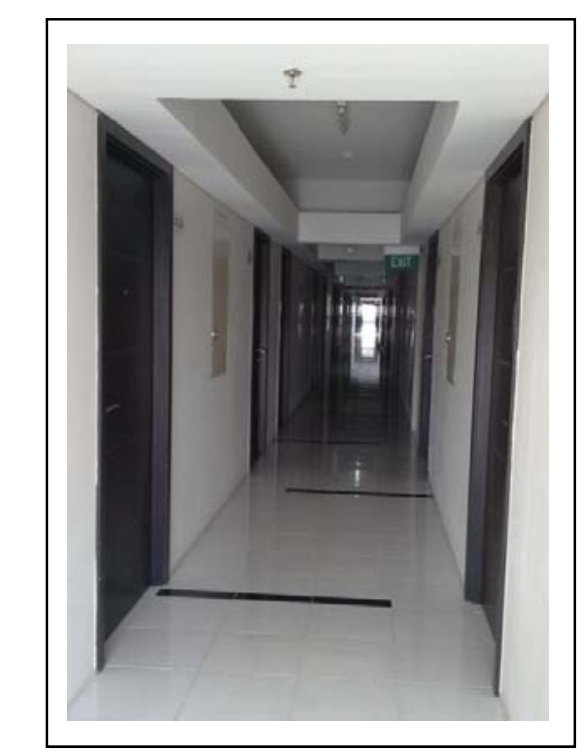

Gambar 10. Area koridor Apartemen Purimas Sumber: Hasil Observasi (2016)

Seperti area koridor pada umumnya, koridor antar unit pada Apartemen Purimas juga tertutup dengan jendela sebagai akses cahaya alami masuk. Suasana pada area ini tidak seramai lobi, cenderung tenang dan bersih rapi, karena tidak ada penghuni yang meninggalkan barang pribadinya didepan unit (Gambar 10).

Rapoport (2005) menjelaskan bahwa fenomena perilaku di apartemen harus dilihat secara khusus. Lingkungan sangat berpengaruh terhadap perilaku. Setelah mencermati karakter lingkungan luar apartemen, maka diperoleh karakter umum perilakunya yaitu kemudahan memperoleh kebutuhan sehari hari, fasilitas umum dapat dicapai dengan berjalan kaki. Ada kemudahan bagi warga perumahan dan penghuni apartemen Purimas dalam memanfaatkan fasilitas umum (Ada club house yang terdiri atas sarana kolam renang, lapangan tenis dan sarana fitnes). Pos keamanan selain terdapat di pintu utama perumahan, juga ada di setiap kluster.

\section{A. Karakter Perilaku di Kolam Renang}

Kolam renang apartemen Purimas terletak di lantai 1 yaitu di belakang area resepsionis lobi (Gambar 11). Di pintu lobi terdapat sistem akses masuk sebagai bagian dari pengamanan bagi penghuni. Hal ini berupa sistem pengunci yang dibuka pada saat saat tertentu. Oleh karenanya kolam renang menjadi area publik yang privasi, karena hanya untuk penghuni apartemen saja. Secara fisik terletak di lantai 1 yaitu yang diperuntukkan bagi fasilitas penunjang, namun secara non fisik khusus menjadi privasi penghuni. Akses kolam renang yang hanya dapat dicapai oleh orang dalam tersebut memperkuat keterikatan penghuni terhadap fungsi kolam renang. Penghuni bebas memanfaatkan. Hal tersebut nampak pada cara okupansi yang dilakukan penghuni. Mereka dengan nyaman sudah mengenakan pakaian renang sejak dari unit kamar. Demikian pula untuk berganti pakaian mereka lebih memilih di unit kamar daripada di kamar mandi kolam renang. Kolam renang dan unit kamar menjadi ruang yang 'dekat'. Secara fisik terpisah oleh 'jarak' karena harus melewati koridor, lift dan lobi, namun secara non fisik tidak menjadi penghalang bagi penghuni dalam cara berpakaian. Sikap duduk 
penghuni ketika di area kolam renang sangat santai berkesan bebas (mengangkat kaki di atas kursi, menggunakan 2 kursi untuk sandaran kaki , dan sebagainya)

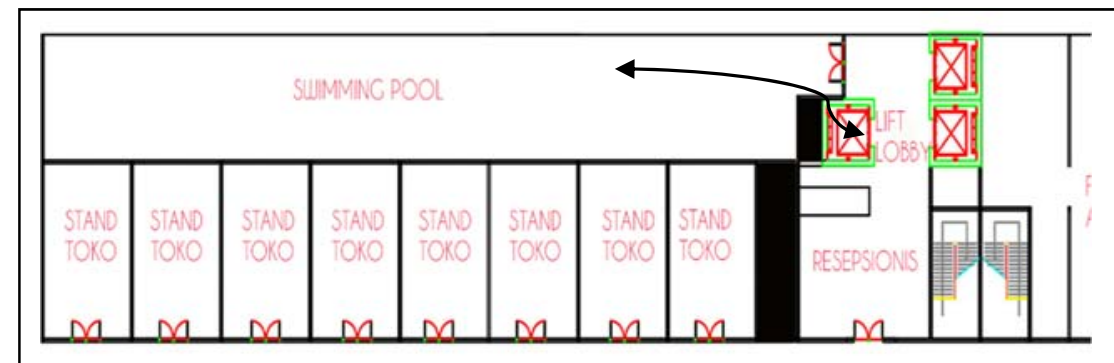

Gambar 11. Lokasi Kolam Renang sebagai Fasilitas Penunjang di Apartemen Purimas Sumber: Hasil Observasi (2016)

Keterikatan penghuni dalam memanfaatkan kolam renang tidak dibatasi waktu, jarak dan sistem akses. Di area inilah sering terjadi interaksi antar penghuni. Pada hari biasa, saat pagi atau siang didominasi oleh wanita dewasa atau ibu rumah tangga yang mengasuh anak (Gambar 12). Anak sekolah lebih memanfatkan ketika sore hari atau saat libur sekolah. Sedangkan malam hari dimanfaatkan oleh orang dewasa.

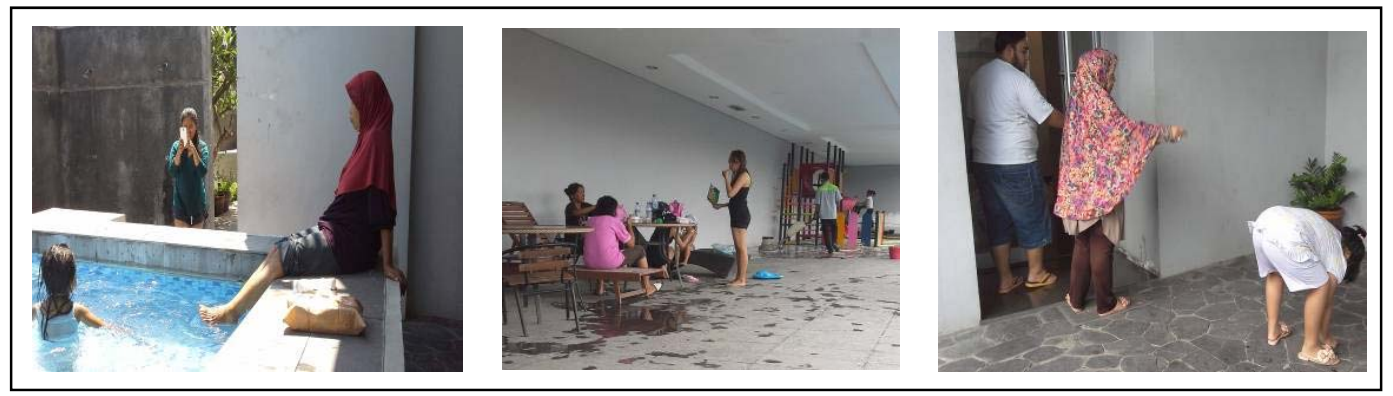

Gambar 12. Okupansi Penghuni di Kolam Renang Apartemen Purimas Sumber: Hasil Observasi (2016)

Hal yang paling menonjol dan menarik bahwa okupansi penghuni terhadap area kolam renang sudah dilakukan sejak dari unit kamar. Mereka nampak sudah terbiasa serta percaya diri mengenakan baju renang. Sehingga lobi, koridor dan lift yang merupakan 'jalur lintasan' menjadi ruang personal. Yaitu ruang yang diokupansi seperti halnya unit kamar. Pada umumnya bila orang dewasa mereka menutup badan dengan baju handuk atau baju mandi. Ketika berpapasan dengan penghuni lain hal atau perilaku yang mereka lakukan adalah mempercepat langkah kaki. Waktu 'tempuh' yang sebentar dengan adanya lift, menjadi keterikatan yang aman dan dekat ke kolam renang

\section{B. Karakter Perilaku di Foodcourt dan Toko}

Foodcourt dan toko terletak di lantai dasar, menghadap langsung ke area parkir serta dapat diakses dari luar tanpa melewati lobi. Kemudahan akses tersebut ditunjang pula secara visual yaitu desain dinding foodcorurt dan toko yang transparan berupa dinding kaca yang nampak jelas dari luar. Selain penghuni apartemen, konsumennya adalah pengunjung serta masyarakat sekitar apartemen. Sehingga foodcourt dan toko bersifat publik. Penghuni apartemen bertemu dengan pengunjung di area tersebut. Ketersediaan meja dan kursi di foodcourt yang cukup memadai jumlahnya menjadi sarana alternatif bagi penghuni maupun pengunjung untuk 
berkumpul, menerima tamu, bahkan untuk refreshing. Sehingga fungsi foodcourt tidak hanya sebagai ruang makan, namun juga menjadi ruang pertemuan dan ruang 'kerja' serta refreshing (Gambar 13 dan 14)

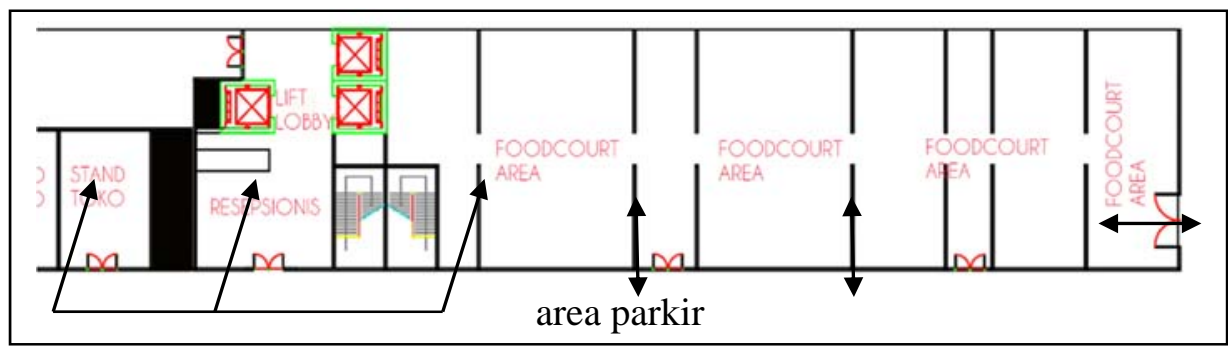

Gambar 13. Foodcourt \& Toko sebagai Fasilitas Penunjang Apartemen Purimas Sumber: Hasil Observasi (2016)

Penghuni dapat memesan makanan dari foodcourt dan barang dari toko, serta dapat diantar hingga unit kamar. Penjual dapat mengakses lift menuju lantai unit kamar penghuni pemesan dengan bantuan petugas sekuriti. Kemudahan sistem pemesanan tersebut menjadi keterikatan keberadaan kepemilikan bersama yang menunjang kebutuhan penghuni apartemen. Akses bantuan dari petugas sekuriti karena ada kepercayaan dan sudah saling mengenal dengan baik.

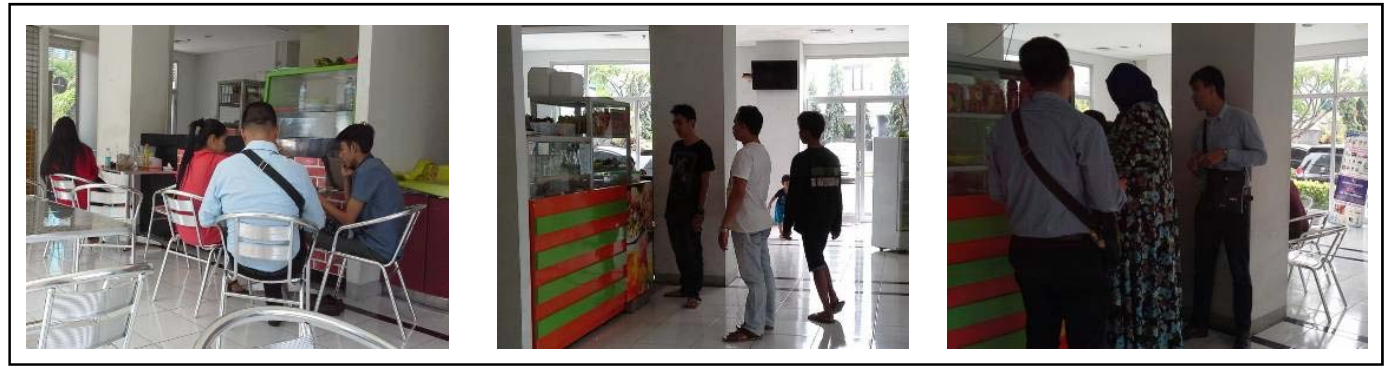

Gambar 14. Okupansi Penghuni di Foodcourt Apartemen Purimas Sumber: Hasil Observasi (2016)

\section{Karakter Perilaku di Area Parkir}

Fasilitas penunjang yang cukup penting adalah area parkir. Halaman depan apartemen mempunyai fungsi utama sebagai lahan parkir. Selain di halaman depan, area parkir terdapat pula di basement. Kendaraan yang memasuki lokasi apartemen Purimas harus melewati sistem keamanan otomatis guna membuka palang pintu gate kawasan apartemen (Gambar 15). Penghuni maupun pengunjung memperoleh tanda masuk secara digital. Keuntungan dari sistem tersebut adalah penghuni merasa aman karena terpantau dan terjaga keamanannya. Sistem akan merekam nomor plat mobil penghuni yang telah terdaftar di pihak manajemen pengelola. Bagi nomor mobil penghuni yang sudah terdaftar maka tidak dikenakan biaya parkir, sebaliknya bagi yang tidak terdaftar (pengunjung) harus membayar.

Perekaman nomor mobil penghuni merupakan sistem yang melindungi penghuninya. Manajemen pengelola menerapkan privasi lingkungan apartemen bagi penghuni sejak memasuki kawasan atau halaman parkir apartemen. Namun karena halaman parkir juga dapat diakses oleh pengunjung, maka penghuni yang menghendaki 'langganan' area parkir khusus, disediakan di lantai basement. Keamanan kendaraan penghuni dengan adanya sistem parkir yang melalui pos pantau digital berpengaruh pada rasa aman dalam pemanfaatan fasilitas yang lain. Penghuni telah merasa berada di lingkungan privasi karena adanya keterjaminan keamanan 
tersebut. Pada umumnya petugas sekuriti hafal dan mengenal penghuni apartemen, walaupun tidak tahu namanya. Mereka selalu bertegur sapa seperti keluarga. Bahkan petugas cukup hafal dengan kendaraan yang dimiliki penghuni, sehingga komunikasi nampak akrab.

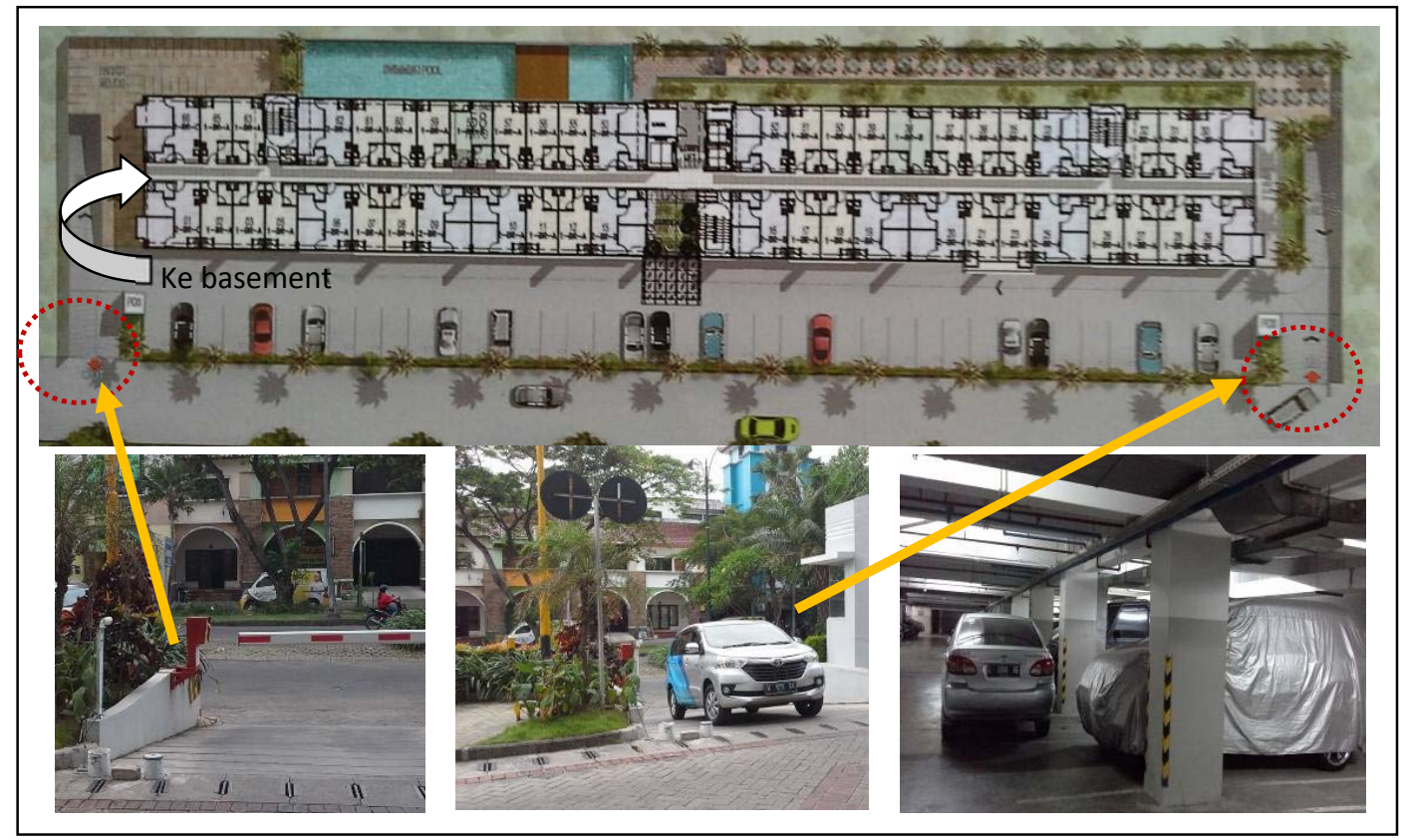

Gambar 15. Area Parkir dan Sistem Pengaman Parkir Apartemen Purimas Sumber: Hasil Observasi (2016)

Untuk kondisi tertentu, ketika ramai pengunjung area parkir mobil penghuni apartemen hingga ke taman depan apartemen. Karena dalam manajemen pengelolaan yang sama maka taman perumahan Purimas tersebut dapat digunakan sebagai lahan parkir apartemen yang tentative. Keberadaan parkir tentative tersebut tidak mengganggu lalu lintas perumahan (Gambar 16).

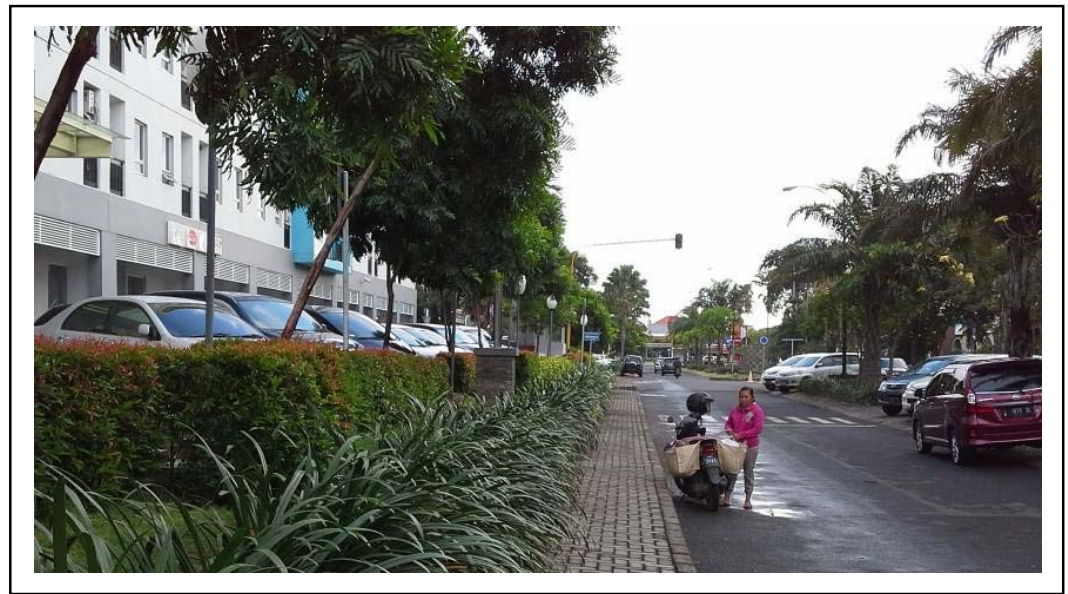

Gambar 16. Area Parkir Tambahan Penghuni Apartemen Purimas Sumber : Hasil Observasi (2016) 
Berdasarkan karakter fasilitas penunjang apartemen di atas, maka nampak ada keterkaitan dengan karakter lingkungan luarnya. Karakter lingkungan luar apartemen adalah perumahan, dengan fasilitas umum penunjang kebutuhan hunian yang mudah diperoleh, yaitu jarak yang cukup dekat. Penghuni apartemen dapat memenuhi kebutuhannya dengan berjalan kaki. Kemudahan orientasi dan akses pencapaian menuju apartemen menyebabkan banyak layanan yang menguntungkan. Hal tersebut berdampak pada kualitas fasilitas penunjang apartemen. Tabel 1, 2 dan 3 berikut menunjukkan interaksi pelaku pengguna fasilitas penunjang apartemen, beserta karakter perilaku yang terjadi.

Tabel 1. Karakter Umum Perilaku Penghuni dalam Hubungan dengan Pengguna lain di Fasilitas Penunjang Apartemen Purimas

\begin{tabular}{|l|l|l|l|}
\hline \multicolumn{1}{|c|}{$\begin{array}{c}\text { Karakter } \\
\text { Interaksi }\end{array}$} & \multicolumn{1}{|c|}{ Kolam renang } & \multicolumn{1}{c|}{ Foodcourt } & \multicolumn{1}{c|}{ Area parkir } \\
\hline $\begin{array}{l}\text { Penghuni- } \\
\text { penghuni }\end{array}$ & $\begin{array}{l}\text { Berenang } \\
\text { Mengasuh anak } \\
\text { Refreshing } \\
\text { Fitness }\end{array}$ & $\begin{array}{l}\text { Makan } \\
\text { Mengasuh anak } \\
\text { Kerja } \\
\text { refreshing }\end{array}$ & $\begin{array}{l}\text { Parkir mobil } \\
\text { Menunggu penjual } \\
\text { sayur } \\
\text { Menunggu jemputan }\end{array}$ \\
\hline $\begin{array}{l}\text { Penghuni- } \\
\text { pengunjung }\end{array}$ & & $\begin{array}{l}\text { Makan } \\
\text { Pertemuan/meeting }\end{array}$ & $\begin{array}{l}\text { - Parkir mobil } \\
- \text { Antar dan ambil } \\
\text { hasil laundry }\end{array}$ \\
\hline $\begin{array}{l}\text { Penghuni- } \\
\text { petugas }\end{array}$ & & Delivery order & $\begin{array}{l}\text { - Parkir mobil } \\
- \text { Bawa barang } \\
- \text { Informasi }\end{array}$ \\
\hline $\begin{array}{l}\text { Pengunjung- } \\
\text { petugas }\end{array}$ & & Pesan makanan & $\begin{array}{l}\text { Parkir mobil } \\
\text { - Informasi }\end{array}$ \\
\hline
\end{tabular}

Sumber: Astuti, SB (2018)

Tabel 2. Karakter Perilaku Penghuni Secara Fisik dan Non Fisik di Fasilitas Penunjang Apartemen Purimas

\begin{tabular}{|l|l|l|}
\hline & \multicolumn{1}{|c|}{ Fisik } & \multicolumn{1}{|c|}{ Non Fisik } \\
\hline Kolam Renang & $\begin{array}{l}\text { Berpakaian renang sejak dari unit } \\
\text { kamar. Jalur lintasan (Koridor, lift } \\
\text { dan lobi) menjadi personal } \\
\text { okupansi }\end{array}$ & $\begin{array}{l}\text { - Kolam renang menjadi } \\
\text { fasilitas penunjang yang khusus } \\
\text { bagi penghuni } \\
\text { - Tidak ada biaya } \\
\text { - Bebas memanfaatkan }\end{array}$ \\
\hline $\begin{array}{l}\text { Foodcourt \& } \\
\text { Toko }\end{array}$ & $\begin{array}{l}\text { - Foodcourt sebagai ruang makan, } \\
\text { pertemuan, kerja dan refreshing } \\
\text { - Toko sebagai penyedia } \\
\text { kebutuhan sehari hari }\end{array}$ & $\begin{array}{l}\text { - Makanan dan barang dapat } \\
\text { dipesan dan diantar ke unit } \\
\text { kamar. } \\
\text { - saling mengenal dengan baik }\end{array}$ \\
\hline Area Parkir & $\begin{array}{l}\text { - Sistem digital, nomor mobil } \\
\text { penghuni terdaftar di pihak } \\
\text { manajemen. }\end{array}$ & $\begin{array}{l}\text { Tidak berbayar } \\
\text { mengenal dengan baik dan } \\
\text { hafal dengan petugas }\end{array}$ \\
\hline
\end{tabular}

Sumber: Astuti, SB (2018) 
Tabel 3. Interaksi Penghuni dengan Pengguna Lain, dimulai dari Unit Kamar, Koridor, Lobi hingga ke Fasilitas Penunjang Apartemen

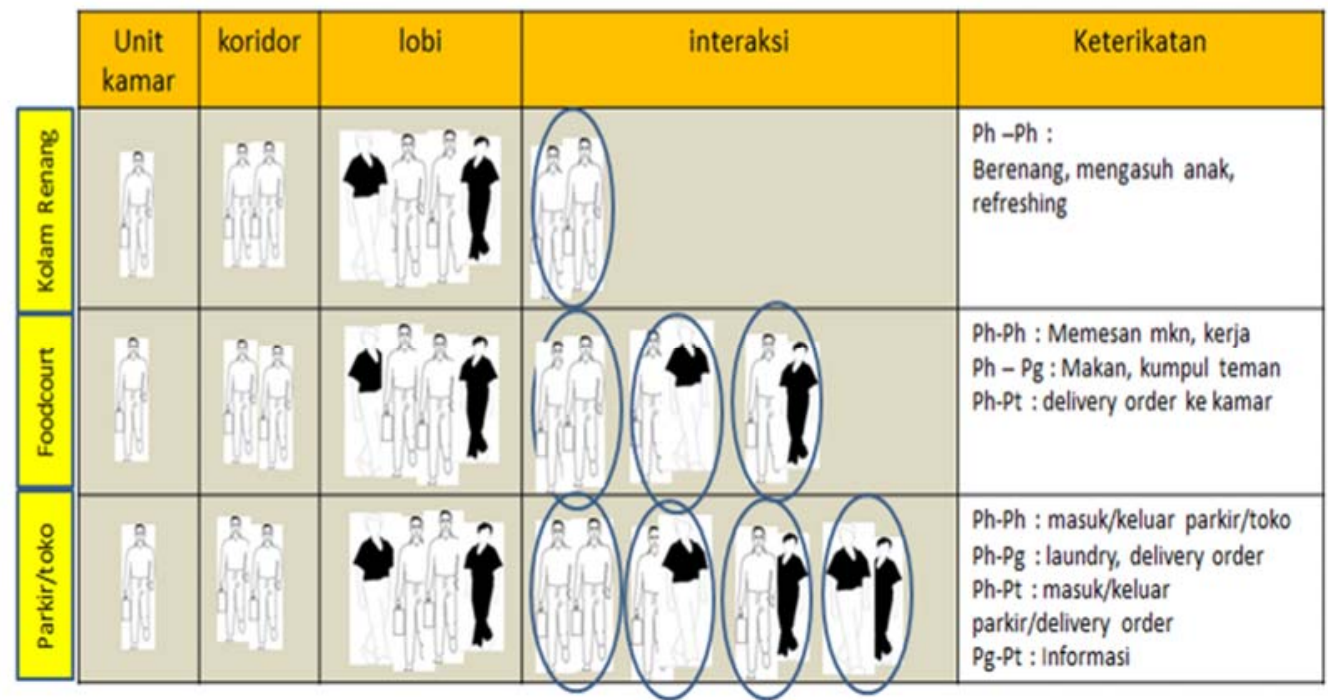

Sumber: Astuti, SB (2018)

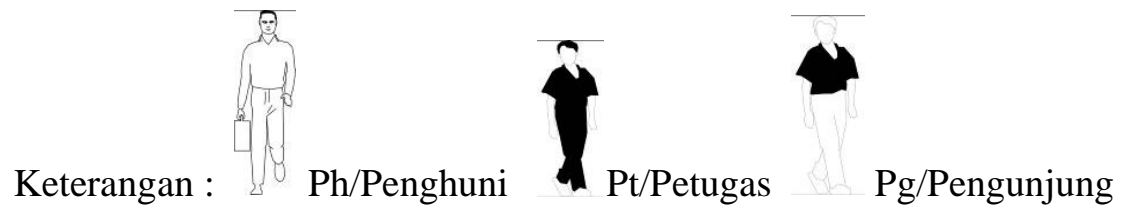

Berikut resume tentang hubungan karakter lingkungan dengan perilaku penghuni di fasilitas penunjang apartememen. Apartemen Purimas merupakan apartemen yang tidak terintegrasi dengan fasilitas umum lain (misal : mall, perkantoran dll). Sehingga pengguna di bangunan tersebut adalah mayoritas penghuni yang menempati unit kamar apartemen. Pengunjung yang datang adalah yang berkepentingan dengan unit kamar apartemen, baik terhadap penghuni maupun kebutuhan unit kamarnya. Di dalam memenuhi kebutuhan sehari hari apartemen Purimas menyediakan fasilitas penunjang foodcourt serta toko kebutuhan pokok. Untuk kebutuhan pelengkap, misalnya laundry, peralatan rumah tangga, supermarket 24 jam dan lain lain, dapat diperoleh di lingkungan perumahan dan sekitar apartemen. Fasilitas pelengkap tersebut cukup dekat sehingga dapat dicapai dengan berjalan kaki.

Tersedianya area parkir basement, merupakan sarana alternatif bagi penghuni untuk ‘menyimpan' mobil bila tidak digunakan atau menjadi lahan parkir aternatif yang lebih privasi. Petugas mengenal si pemilik mobil, walaupun tidak tahu namanya. Petugas selalu menegur dan menyapa pemilik mobil. Perilaku di area parkir tersebut membuat perasaan aman penghuni. Keterikatan pada area parkir bukan hanya ketersediaan sarananya yang merupakan kepemilikan bersama, namun lebih pada hubungan baik dengan petugas.

Kolam renang apartemen Purimas secara fisik berada di lantai 1, namun peruntukannya bersifat khusus bagi penghuni. Penghuni mudah mengakses secara bebas, sehingga hal tersebut berdampak pada ‘melebar'nya ruang personal karena penghuni berperilaku secara privasi yaitu ditandai dengan cara duduk yang santai, cara berpakaian (baju renang, celana pendek dan kaos santai), serta barang bawaan yang bersifat pribadi (handuk, sabun, sisir, dll). Tabel 4 berikut menunjukan karakter perilaku penghuni di fasilitas penunjang. Pengamatan secara kuantitas jumlah prosentase penggunaan dilakukan terhadap setiap 5 pengunjung di fasilitas tersebut. 
Vol. 3, No. 2, Desember 2018, pISSN 2527-2853, eISSN 2549-2985

Tabel 4. Karakter Perilaku di Fasilitas Penunjang Apartemen Purimas

\begin{tabular}{|c|c|c|c|c|c|}
\hline $\begin{array}{c}\text { Fasilitas } \\
\text { Penunjang }\end{array}$ & Sarana & $\begin{array}{c}\text { Jenis } \\
\text { Aktivitas }\end{array}$ & $\begin{array}{c}\text { Rata2 } \\
\text { frekuensi } \\
(\%)\end{array}$ & Interaksi & $\begin{array}{l}\text { Karakter Perilaku \& } \\
\text { Karakter Lingkungan }\end{array}$ \\
\hline \multirow{4}{*}{$\begin{array}{l}\text { Area } \\
\text { Kolam } \\
\text { renang }\end{array}$} & $\begin{array}{l}\text { Kolam } \\
\text { renang }\end{array}$ & Berenang & 35 & \multirow[t]{4}{*}{$\begin{array}{l}\text { Antar } \\
\text { Penghuni }\end{array}$} & \multirow{4}{*}{$\begin{array}{l}\text { Penghuni berperilaku } \\
\text { privasi seperti hal nya } \\
\text { di unit kamar, ditandai } \\
\text { dari cara duduk, } \\
\text { pakaian dan barang } \\
\text { bawaan. } \\
\text { Melewati sistem akses } \\
\text { khusus }\end{array}$} \\
\hline & $\begin{array}{l}\text { Meja \& } \\
\text { kursi }\end{array}$ & $\begin{array}{l}\text { Menunggu, } \\
\text { mengobrol, } \\
\text { mengasuh } \\
\text { anak }\end{array}$ & 25 & & \\
\hline & $\begin{array}{l}\text { playgro } \\
\text { und }\end{array}$ & bermain & 20 & & \\
\hline & $\begin{array}{l}\text { Alat } \\
\text { fitness }\end{array}$ & fitness & 20 & & \\
\hline Foodcourt & $\begin{array}{l}\text { Meja \& } \\
\text { kursi }\end{array}$ & $\begin{array}{l}\text { Makan } \\
\text { minum } \\
\text { Kerja } \\
\text { Refreshing/ } \\
\text { ngobrol } \\
\text { dengan } \\
\text { teman }\end{array}$ & $\begin{array}{l}60 \\
20 \\
20\end{array}$ & $\begin{array}{l}\text {-Antar } \\
\text { penghuni } \\
\text {-Penghuni } \\
\text { dan } \\
\text { pengunjung } \\
\text {-Penghuni } \\
\text { dan petugas }\end{array}$ & $\begin{array}{l}\text { Perilaku publik dapat } \\
\text { berubah menjadi privasi } \\
\text { dengan adanya layanan } \\
\text { dan ijin mengantar } \\
\text { barang hingga unit } \\
\text { kamar. } \\
\text { Ruang menghadap } \\
\text { ruang luar, dinding } \\
\text { kaca, tanda ruang } \\
\text { publik. Bisa diakses } \\
\text { oleh pengunjung. }\end{array}$ \\
\hline Toko & $\begin{array}{l}\text { Display } \\
\text { barang }\end{array}$ & $\begin{array}{l}\text { Membeli } \\
\text { barang } \\
\text { Melihat } \\
\text { barang }\end{array}$ & $\begin{array}{l}20 \\
80\end{array}$ & $\begin{array}{l}\text { - Penghuni } \\
\text { dan } \\
\text { pengunjung } \\
\text { - Penghuni } \\
\text { dan petugas }\end{array}$ & $\begin{array}{l}\text { Perilaku publik dapat } \\
\text { berubah menjadi privasi } \\
\text { dengan adanya layanan } \\
\text { dan ijin mengantar } \\
\text { barang hingga unit } \\
\text { kamar. } \\
\text { Ruang menghadap } \\
\text { ruang luar, dinding } \\
\text { kaca, tanda ruang } \\
\text { publik. Bisa diakses } \\
\text { oleh pengunjung. }\end{array}$ \\
\hline Parkir & $\begin{array}{l}\text { Lahan } \\
\text { parkir }\end{array}$ & $\begin{array}{l}\text { Memarkir } \\
\text { kendaraan }\end{array}$ & 100 & $\begin{array}{l}\text { - Penghuni } \\
\text { dan Petugas }\end{array}$ & $\begin{array}{l}\text { Perilaku publik } \\
\text { Ada sistem akses digital } \\
\text { dan perekaman nomor } \\
\text { kendaraan, sehingga } \\
\text { ada rasa aman } \\
\text { walaupun di ruang } \\
\text { publik }\end{array}$ \\
\hline
\end{tabular}

Sumber: Astuti, SB (2018) 


\section{KESIMPULAN}

Lingkungan sebagai setting fisik wadah perilaku, membentuk karakter perilaku penghuninya. Hubungan timbal balik antara setting, perilaku dan penghuni apartemen (user) menjadi pembentuk keberlangsungan kehidupan di apartemen.

Karakter lingkungan makro secara fisik maupun non fisik mempengaruhi karakter lingkungan mikro. Perilaku penghuni Apartemen Purimas sangat dipengaruhi oleh karakter ruang ruang atau fasilitas penunjangnya. Sementara itu, fasilitas penunjang apartemen mempunyai keterikatan pula dengan karakter lingkungan perumahan Purimas. Pola interaksi sosial yang terjadi sesama penghuni atau dengan pengunjung/petugas menentukan keberlangsungan kehidupan sosial di hunian vertikal, khususnya apartemen.

\section{DAFTAR PUSTAKA}

Altman, I dan Chemeers, M. (1980). The Environment and Social Behavior. Wadsworth: Monterey, CA.

Aziz dkk. (2013). Block Level Social Contacts in Low-Cost Flats. Asian Journal of Environment Behavior Studies. Vol. 4, No. 4, Hal. 97-113.

Baker. (1995). Mildwest and Its Children. New York: Row Peterson.

Farida. (2013). Effect of Outdoor Share Spaces on Social Interaction in Housing Estate in Algeria. Frontier of Architectural Research. Vol. 2, Hal. 457-467.

Haryadi dan Setiawan, B. (1995). Arsitektur Lingkungan dan Perilaku. Yogyakarta: Proyek Pengembangan Pusat Studi Dirjen Dikbud.

Lang, J \& Moleski Walter. (2010). Functionalism Revisited. England: Ashgate Publishing Limited.

Rapoport, A. (1986). The Use and Design of Open Space in Urban Neighborhoods. Berlin: D Frick eds The Quality of Urban Life.

Rapoport, A. (2005). Culture Architecture and Design. USA: Locke Science Publishing Company.

Snyder, J. C. \& Catanese, A. J. (1979). Introduction to Architecture. New York: McGraw-Hill.

Zeisel, John. (1984). Inquiry by Design: Tools for Environment-Behavior Research. Cambridge: University Press. 